\title{
Erratum: Biological activity and microscopic characterization of Lythrum salicaria L
}

\author{
Azadeh Manayi ${ }^{1}$, Mahnaz Khanavi ${ }^{1,2}$, Soodabeh Saeidnia ${ }^{3}$, Ebrahim Azizi ${ }^{4}$, Mohammad Reza Mahmoodpour ${ }^{1}$, \\ Fatemeh Vafi ${ }^{1}$, Maryam Malmir ${ }^{5}$, Farideh Siavashi ${ }^{6}$ and Abbas Hadjiakhoondi ${ }^{1,3^{*}}$
}

\section{Text}

After publication of this work [1] authors' noted that the name of 3rd author (Soodabeh Saeidnia) was misspelled. The correct spelling is Soodabeh Saeidnia.

\begin{abstract}
Author details
'Department of Pharmacognosy, Faculty of Pharmacy, Tehran University of Medical Sciences, Tehran, Iran. ${ }^{2}$ Traditional Iranian Medicine and Pharmacy Research Center, Tehran University of Medical Sciences, Tehran, Iran. ${ }^{3}$ Medicinal Plants Research Center, Faculty of Pharmacy, Tehran University of Medical Sciences, Tehran, Iran. ${ }^{4}$ Department of Pharmacology and Toxicology, Faculty of Pharmacy, Tehran University of Medical Sciences, Tehran, Iran. ${ }^{5}$ Med.UL, Faculty of Pharmacy, University of Lisbon, Lisbon, Portugal. ${ }^{6}$ Microbiology Department, Faculty of Sciences, University of Tehran, Tehran, Iran
\end{abstract}

Received: 7 August 2014 Accepted: 8 August 2014

Published online: 09 October 2014

\section{Reference}

1. Azadeh M, Mahnaz K, Soodabeh S, Ebrahim A, Mohammad Reza M, Fatemeh V, Maryam M, Farideh S, Abbas H: Biological activity and microscopic characterization of Lythrum salicaria L. DARU J Pharm Sci 2013, 21:61.

\section{doi:10.1186/s40199-014-0061-x}

Cite this article as: Manayi et al.: Erratum: Biological activity and microscopic characterization of Lythrum salicaria L. DARU Journal of Pharmaceutical Sciences 2014 22:61.

\footnotetext{
* Correspondence: abbhadji@razi.tums.ac.ir

'Department of Pharmacognosy, Faculty of Pharmacy, Tehran University of Medical Sciences, Tehran, Iran

${ }^{3}$ Medicinal Plants Research Center, Faculty of Pharmacy, Tehran University of
} Medical Sciences, Tehran, Iran

\section{Submit your next manuscript to BioMed Central and take full advantage of:}

- Convenient online submission

- Thorough peer review

- No space constraints or color figure charges

- Immediate publication on acceptance

- Inclusion in PubMed, CAS, Scopus and Google Scholar

- Research which is freely available for redistribution

Submit your manuscript at www.biomedcentral.com/submit

( Biomed Central

\section{Biomed Central}

(c) 2014 Manayi et al.; licensee BioMed Central Ltd. This is an Open Access article distributed under the terms of the Creative Commons Attribution License (http://creativecommons.org/licenses/by/4.0), which permits unrestricted use, distribution, and reproduction in any medium, provided the original work is properly credited. The Creative Commons Public Domain Dedication waiver (http://creativecommons.org/publicdomain/zero/1.0/) applies to the data made available in this article, unless otherwise stated. 